\title{
PKMS KELOMPOK BELAJAR PASRAMAN SWASTA PRANAWA KELURAHAN ABIANTUBUH BARAT, KELURAHAN ABIANTUBUH BARU, KECAMATAN SANDUBAYA, KOTA MATARAM
}

\author{
Oleh \\ I Ketut Purwata, Si Luh Putu Damayanti, Lalu Yulendra \& I Ketut Bagiastra \\ Sekolah Tinggi Pariwisata Mataram \\ Email: ${ }^{1}$ ketutpurwata@gmail.com
}

\begin{abstract}
Abstrak
Pendidikan keagamaan khususnya umat Hindu baik secara formal dan non formal masih sangat terbatas. Sebagai gambaran bahwa dari 196 sekolah dasar yang ada di kota mataram baik Negeri maupun swasta tercatat hanya 40 jumlah guru agama Hindu PNS (Kendikbud NTB,2019). Artinya bahwa masih banyak siswa yang tidak memiliki pendidik Agama Hindu. Kurangnya pendidik Agama Hindu di Kota Mataram secara hirarki juga berlaku di semua tingkatan sampai dengan kelurahan-kelurah. Lingkungan Abiantubuh Barat, Kelurahan Abiantubuh Baru, Kecamatan Sandubaya, Kota Mataram yang menjadi tempat atau wilayah kerja Pura Dalem Swasta Pranawa, yang di empon oleh enam lingkungan yang ada sekitarnya seperti Lingkungan Panaraga Utara, Panaraga Selatan, Abiantubuh Utara, Abiantubuh Selatan, Abiantubuh Barat, dan Gedur mengalami hal yang sama yaitu sangat minim memiliki tempat atau pendidik yang memberikan pendidikan Agama Hindu. Masih rendah pemahaman dan pengetahuan pengempon (masyarakat) Pura Dalem Swasta Pranawa (PDSP) sebagai wadah induk hasil Pasraman, mengenai keberadaan, peran dan manfaat kegiatan kelompok belajar Pasraman saat ini dan kedepannya. Setelah ada PKMs masyarakat memahami dan mengetahui manfaat dan arti pentingnya kelompok belajar Pasraman bagi sisie dan masyarakat. Sedang untuk pembina menjadi landasan untuk menentukan kebijakan dan arah pasraman. Bagi pengelola dan Brahmecari (pengajar)paham tentang pemanfaatan administrasi pendidikan, dan memanfaatkan sumberdaya yang ada Pasraman untuk memperlancar proses belajar mengajar dan meningkatkan peran dan keberlanjutan Pasraman. Kelompok belajar Pasraman Swasta Pranawa telah memperoleh kemampuan dalam pengelolaan administrasi pendidikan Pasraman, pengadaan sarana pendidikan, perawatan dan perbaikan peralatan, pemanfaatan peralatan secara maksimal untuk melakukan proses pembelajaran dan melakukan promosi dengan teknologi informatika komputer dan gawai (on line atau off line) serta pemberdayaan Pasraman yang bermanfaat untuk masyarakat.Saran dari kegiatan pengabdian ini adalah Mitra membutuhkan pendampingan yang berkelanjutan dalam pelaksanaan proses belajar mengajar, pengembangan dan keberlanjutan Pasraman, sehingga bisa di jadikan sebagai alternatif yang positif dalam penanganan pendidikan non formal dewasa ini.
\end{abstract}

Kata Kunci: Kelompok Belajar Pasraman, Kelurahan Abiantubuh Barat

\section{PENDAHULUAN}

\section{Analisis Situasi}

Globalisasi dan kemajuan tehnologi disamping membawa dampak positif juga membawa dampak negatif. Dampak negatif tersebut seperti bergesernya dan nilai-nilai luhur bangsa seperti, melemahnya keyakinan agama, sosial budaya dan kearifan lokal. Pendidikan menjadi jalan keluar permasalahan ini. Undang-undang Nomor 20 Tahun 2003 menjelaskan bahwa pendidikan adalah usaha sadar dan terencana untuk mewujudkan suasana belajar dan proses pembelajarn agar peserta didik secara aktif mengembangkan potensi dirinya untuk memiliki kekuatan spiritual, keagamaan, pengendalian diri, kepribadian, kecerdasan, ahlak mulia, serta keterampilan yang diperlukan dirinya, masyarakat, Bangsa dan Negara. Dalam pendidikan yang baik, akan memberikan pemahaman kepada siswa 
mengenai pengetahuan agama dan budaya. Dalam hal pendidikan keagamaan khususnya umat Hindu baik secara formal dan non formal masih sangat terbatas. Sebagai gambaran bahwa dari 196 sekolah dasar yang ada di kota mataram baik Negeri maupun swasta tercatat hanya 40 jumlah guru agama Hindu PNS (Kendikbud NTB,2019). Artinya bahwa masih banyak siswa yang tidak memiliki pendidik Agama Hindu.

Kurangnya pendidik Agama Hindu di Kota Mataram secara hirarki juga berlaku di semua tingkatan sampai dengan kelurahankelurah. Lingkungan Abiantubuh Barat , Kelurahan Abiantubuh Baru, Kecamatan Sandubaya, Kota Mataram yang menjadi tempat atau wilayah kerja Pura Dalem Swasta Pranawa, yang di empon oleh enam lingkungan yang ada sekitarnya seperti Lingkungan Panaraga Utara, Panaraga Selatan, Abiantubuh Utara, Abiantubuh Selatan, Abiantubuh Barat, dan Gedur mengalami hal yang sama yaitu sangat minim memiliki tempat atau pendidik yang memberikan pendidikan Agama Hindu. Bahkan secara obyektif dilapangan sebaran siswa Hindu diberbagai tingkatan pendidikan tidak mendapatkan pendidikan Agama Hindu secara maksimal pada pendidikan formal di sekolah, sedangkan nilai agama merupakan mata pelanjaran inti. Disisi lain, perkembangan kondisi sosial masyarakat dewasa ini kususnya bagi generasi muda yang akan menjadi penerus bagi keberlanjutan bangsa dan negara secara pasti terus mengalami distorsi orientasi, terutama pengaruh-pengaruh pergaulan yang merusak moral, ahlak seperti pergaulan bebas, perjudian, minuman keras, narkoba sangat mengancam secara nyata dan masif.

Menyadari situasi dan kondisi tersebut I Made Kariana dengan dibantu oleh pengurus Pura Dalem Swasta Prana beserta masyarakat mendirikan kelompok belajar mingguan. Awal pelaksanaan Pasraman ini merupakan pendidikan non formal dimana, proses belajar, tempat dan sarana belajarnya masih sangat sederhana dengan mengandalkan sarana yang ada di Pura Dalam Swasta Pranawa. Adapun mata pelajaran yang di ajarkan di Pasraman adalah Pendidikan Agama Hindu, Yoga
Asanas, Aksara Bali, Dharma Gita, Tari dan seni, Upakara atau keterampilan. Kemudian Pasraman ini pertama kali di sosialisasikan atau perkenalkan kepada masyarakat dengan menyampaikan dari mulut kemulut dan pada saat kegiatan di Pura untuk mendapatkan siswa. Sejak saat itu siswa yang masuk pasraman terus bertambah sampai dengan 75 orang dan setiap minggu ada 50 orang siswa yang hadir. Waktu dan tempat pembinaan dan proses belajar mengajar dilaksanakan setiap hari minggu, jam 09.00 - 12.00 Wita, bertempat di Madya Mandala Pura Dalem Swasta Pranawa, Abiantubuh, Cakranegara. Letak geografis Pasraman ini yaitu di Jalan Senopati Raya Abiantubuh Cakranegara, Kota Mataram. Sejak saat itu diajaklah pengurus dan beberapa masyarakat yang perduli untuk memperkuat Pasraman ini agar terorganisir dengan baik pada tahun 2012 oleh I Made Kariana membentuk Pasraman ini dengan nama "Pasraman Swasta Pranawa".

\subsection{Profil Pasraman Swasta Pranawa.}

Berdasarkan uraian terdahulu, khalayak sasaran pada program Kemitraan Masyarakat Stimulus ini adalah masyarakat Program kemitraan masyarakat ini adalah masyarakat yang memiliki kemampuan untuk melakukan sosial engineering dengan media Agama, sosial dan budaya yaitu kelompok belajar mingguan Pasraman Swasta Pranawa, yang wilayah domisilinya ada di Lingkungan Abiantubuh Barat, Kelurahan Abiantubuh Baru,Kecamatan Sandubaya, Kota Mataram, Propinsi Nusa Tenggara Barat.

Kepengurusan dari Pasraman Swasta Pranawa dapat dilihat pada Tabel 1 sebagai berkut.

Tabel 1. Kepengurasan Pasraman Swasta Pranawa 2019

\begin{tabular}{|l|l|l|}
\hline No & \multicolumn{1}{|c|}{ Nama } & \multicolumn{1}{c|}{ Jabatan } \\
\hline 1 & Ida Wayan Sugata & Ketua/Ketua Pura \\
\hline 2 & Ida Bagus Heri Juniawan & Sekretaris \\
\hline 3 & I Made Kariana & Bendahara \\
\hline 4 & Pemangku Wy Wirgayusa & Perelengkapan \\
\hline 5 & I Wayan Teges & Anggota \\
\hline 6 & Ni Wayan Wiwin & Anggota \\
\hline 7 & Ni Kt Kiran Karismayanti & Anggota \\
\hline & & \\
\hline
\end{tabular}

Sumber : Pasraman Swasta Pranawa (2019) 
Gambar 1 . Alur Proses Pendaftaran Siswa/Sisie,
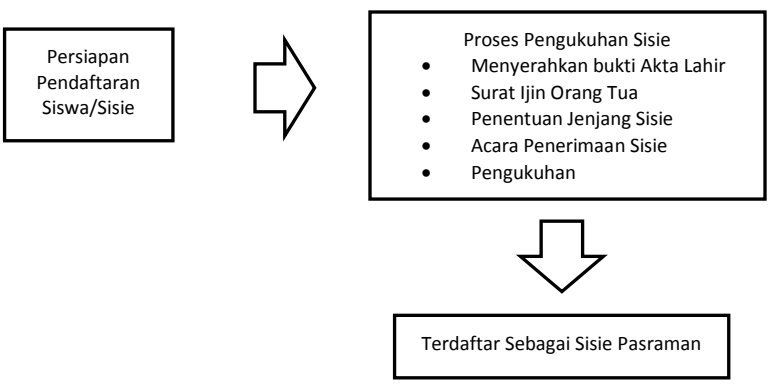

Sumber : Pasraman Swasta Pranawa (2019)

1.2. Manajemen Pasraman Swasta Pranawa.

Siswa dari Pasraman Swasta Pranawa ${ }^{2}$. ini adalah , anak dan masyarakat susai dengan tingkat pendidikan formal dan usia disekitar Lingkungan Gedur Sari, Panaraga Utara, Panaraga Selatan, Abiantubuh Utara, Abiantubuh Selatan, Abiantubuh Barat, Kelurahan Abiantubuh, Cakranegara, Kota Mataram. Dan saat ini menurut informasi dari Pengurus Pasraman Swasta Pranawa sebagai mitra kegiatan pengabdian masyarakat ini, akan dilakukan pengembangan peralatan pendukung proses belajar mengajar yang lebih representatif dan moderen, sudah mulai ada peningkatan peserta didik dan permintaan penambahan siswa. Hal ini belum bisa terpenuhi karena adanya hambatan dari jumlah pengajar dan distribusi waktu dan tempat masih sangat terbatas. Selain itu, manajemen pengelolaan pendidikan masih sangat sederhana dan terbatas dan tenaga pengelolanya masih berganti-ganti.

\section{Permasalahan Mitra.}

\subsection{Permasalahan Peralatan/perlengkapan belajar mengajar.}

1).Permasalahan Mitra dilihat dari peralatan/perlengkapan belajar masih terbatas dan kurang memadai, dan seadanya papan tulis seadanya, meja seadanya dan kurang, tanpa korsi dan sebagainya, sehingga menghambat proses belajar
Tabel 2. Peralatan yang digunakan untuk proses belajar mengajar di Pasraman Swasta Pranawa Tahun 2019

\begin{tabular}{|l|l|c|c|c|}
\hline No & Peralatan & \multirow{2}{*}{$\begin{array}{c}\text { Banyak } \\
\text { Alat }\end{array}$} & \multicolumn{2}{|c|}{ Keadaan } \\
\cline { 4 - 5 } & & Baik & Rusak \\
\hline $\mathbf{1}$ & $\begin{array}{l}\text { Meja lipat } \\
\text { kecil }\end{array}$ & $\mathbf{2 0}$ bh & $\mathbf{1 4}$ bh & $\mathbf{6}$ bh \\
\hline $\mathbf{2}$ & Papan Tulis & $\mathbf{1}$ bh & $\mathbf{1}$ bh & $\mathbf{0}$ bh \\
\hline $\mathbf{3}$ & Tikar & $\mathbf{6}$ bh & $\mathbf{6}$ bh & $\mathbf{0}$ bh \\
\hline $\mathbf{4}$ & $\begin{array}{l}\text { Etalase } \\
\text { Buku }\end{array}$ & $\mathbf{1}$ bh & $\mathbf{1}$ bh & $\mathbf{0}$ bh \\
\hline
\end{tabular}

Sumber: Pasraman Swasta Pranawa, tahun 2019.

. Peralatan/sarana belajar mengajar tidak berumur lama, karena berada di tempat terbuka atau tidak ada tempat penyimpanan khusus. Tidak ada petugas yang khusus merawat dan melakukan penyimpanan, perawatan dan perbaikan peralatan

\subsection{Permasalahan Manajamen pengelolaan belajar mengajar.}

1. Manajemen pengelolaan pembelajaran model Pasraman tidak menganut pengelolaan Pasraman secara moderen, sehingga penyiapan tenaga pengajar, jadwal pembelajaran dan metode pembelajaran masih parsial dan kurang inovatif, sehingga peserta didik merasa jenuh.

2. Kemampuan mensosialisasikan pasraman masih kurang, karena selama ini pasraman hanya di sosialisasikan hanya dari mulut-kemulut dan pada saat ada kegiatan di tempat ibadah saja.

3. Penggunaan media lain dan sarana lain masih belum, dan tidak memiliki papan nama lokasi Pasraman. Oleh karena itu masyarakat akan sulit mengakses profil pasraman dan kegiatan pasraman.

4. Mitra belum terdaptar secara maksimal sebagai Pasraman agar memiliki legalitas dalam melaksanakan operasional. Sehingga pasraman mengalami kesulitan didalam mendapatkan informasi dan bantuan dalam pengembangan pasraman baik secara material maupun non material serta bantuan secara finansial. 
5. Mitra belum melakukan pengelolaan dan pelaporan administrasi dan keuangan secara baik dan benar, sehingga kesulitan dalam perencanaan administrasi laporan dan keuangan.

\section{SOLUSI DAN TARGET LUARAN}

\section{Solusi yang ditawarkan.}

\subsection{Aspek peralatan/perlengkapan}

1). Pengadaan dan penambahan peralatan pendukung proses belajar mengajar

2). Pelatihan dan pendampingan pembuatan sarana dan alat bantu belajar pasraman

\subsection{Aspek Manajemen}

1). Pelatihan manajemen pengelolaan pendidikan Pasraman

2). Pendampingan penyiapan pembuatan perijinan dan penyiapan tenaga pendidik

3). Pelatihan media sosialisasi dan pembuatan plang papan nama mitra

4). Pelatihan pembuat catatan/laporan kegiatan dan keuangan.

\subsection{Peralatan yang ditawarkan untuk mitra} dan telah disepakati adalah sebagai berikut: 1). Koputer Laptop, alat ini sangat membantu memudahkan pekerjaan pada proses pembuatan laporan dan proses belajar mengajar serta mobilisasi informasi.

\section{Gambar 2. Komputer Laptop}

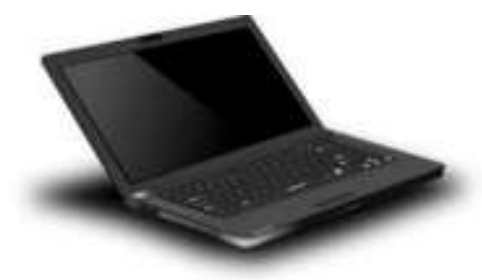

2). Alat LCD dan layar, alat ini sangat membantu sebagai pengganti penyalur gambar dan pengganti papan tulis, untuk mempermudah penggunaan proses blajar mengajar dengan media vidio program.

\section{Gambar 3. Alat LCD dan Layar Scren}
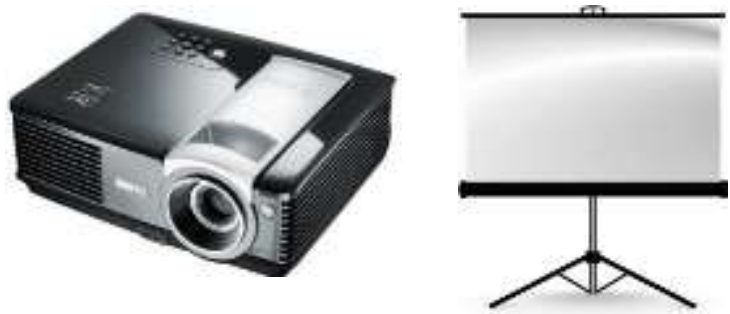

\section{Target Luaran}

Target luaran dari kegiatan PKMS ini, dapat dilihat pada Tabel 3.

\section{Tabel 3. Target Luaran}

\begin{tabular}{|c|c|c|c|}
\hline No & $\begin{array}{c}\text { Aspek } \\
\text { Kegiatan }\end{array}$ & $\begin{array}{l}\text { Target } \\
\text { Luaran }\end{array}$ & Spesifikasi \\
\hline 1 & 2 & 3 & 4 \\
\hline 1 & $\begin{array}{l}\text { Menambah } \\
\text { peralatan } \\
\text { penunjang } \\
\text { belajar } \\
\text { mengajar }\end{array}$ & $\begin{array}{l}\text { Peralatan yang } \\
\text { memadai } \\
\text { untuk } \\
\text { menunjang } \\
\text { proses belajar } \\
\text { mengajar yang } \\
\text { efektif dan } \\
\text { modern }\end{array}$ & $\begin{array}{l}\text { Pengadaan } \\
\text { peralatan belajar } \\
\text { mengajar yang } \\
\text { lebih memadai, } \\
\text { Laptop, Printer, } \\
\text { LCD proyektor, } \\
\text { Lemari buku, } \\
\text { Meja belajar } \\
\text { duduk, Karpet } \\
\text { duduk, White } \\
\text { Board Magnet, } \\
\text { Wareles, Sekat } \\
\text { pembatas ruang, } \\
\text { Cok roll }\end{array}$ \\
\hline 2 & $\begin{array}{l}\text { Menambah } \\
\text { dan } \\
\text { merubah } \\
\text { metode } \\
\text { pengajaran } \\
\text { dan } \\
\text { sosialisasi } \\
\text { Pasraman }\end{array}$ & $\begin{array}{l}\text { Menggunakan } \\
\text { metode media } \\
\text { masa on line } \\
\text { dan gawai. }\end{array}$ & $\begin{array}{l}\text { Pendampingan } \\
\text { dan pelatihan } \\
\text { pembuatan } \\
\text { pemanfaatan } \\
\text { fitur-fitur gawai } \\
\text { dan } \\
\text { memanfaatkan } \\
\text { sarana teknologi } \\
\text { iformasi untuk } \\
\text { mempercepat } \\
\text { dan memperluas } \\
\text { jangkauan } \\
\text { kepada siswa } \\
\text { dan masyarakat. } \\
\text { Disamping itu } \\
\text { memanfaatkan } \\
\text { sarana media ini } \\
\text { untuk } \\
\text { memperluas } \\
\text { metode } \\
\text { pengajaran } \\
\text { dengan vidio } \\
\text { program, } \\
\text { sehingga } \\
\text { mengefisiensi } \\
\text { waktu. }\end{array}$ \\
\hline 3 & $\begin{array}{l}\text { Peningkatan } \\
\text { legalitas } \\
\text { Pasraman }\end{array}$ & $\begin{array}{l}\text { Memiliki } \\
\text { Akta } \\
\text { pendirian dan } \\
\text { adanya ijin } \\
\text { operasional di } \\
\text { Binmas Hindu } \\
\text { di Kemenag. }\end{array}$ & $\begin{array}{l}\text { Pendampingan, } \\
\text { pelatihan } \\
\text { pembuatan dan } \\
\text { tata cara } \\
\text { pengajuan dan } \\
\text { penyampaian } \\
\text { ijin. }\end{array}$ \\
\hline 4 & $\begin{array}{l}\text { Perbaikan } \\
\text { manaje-men }\end{array}$ & $\begin{array}{l}\text { Pemahaman } \\
\text { pengelola-an } \\
\text { administrasi }\end{array}$ & $\begin{array}{l}\text { Pelatihan } \\
\text { membuat catatan }\end{array}$ \\
\hline
\end{tabular}




\begin{tabular}{|c|l|l|l|}
\hline & $\begin{array}{l}\text { pelaporan } \\
\text { keuangan }\end{array}$ & $\begin{array}{l}\text { keu-angan } \\
\text { yang baik. }\end{array}$ & $\begin{array}{l}\text { laporan /laporan } \\
\text { keuangan. }\end{array}$ \\
\hline 5 & $\begin{array}{l}\text { Peningkatan } \\
\text { Sosialisasi } \\
\text { dan promosi }\end{array}$ & $\begin{array}{l}\text { Menjadikan } \\
\text { kegiatan } \\
\text { proses belajar } \\
\text { mengajar } \\
\text { pasraman di } \\
\text { kenal luas. }\end{array}$ & $\begin{array}{l}\text { Membuat plank } \\
\text { nama pasraman, } \\
\text { spanduk, kartu } \\
\text { nama dan } \\
\text { mengajarkan } \\
\text { pembuatan e } \\
\text { commers melalui } \\
\text { media on line. }\end{array}$ \\
\hline
\end{tabular}

\subsection{Indikator keberhasilan}

Rencana Target Capaian Luaran kegiatan PKMs ini, dapat dilihat pada Tabel 4.

Tabel 4. Rencana Target Capaian Luaran

\begin{tabular}{|c|l|l|}
\hline No. & Jenis Luaran & $\begin{array}{l}\text { Indikator } \\
\text { Capaian }\end{array}$ \\
\hline 1 & $\begin{array}{l}\text { Publikasi ilmiah di } \\
\text { jurnal/prosiding }\end{array}$ & Published \\
\hline 2 & $\begin{array}{l}\text { Peningkatan jumlah } \\
\text { peserta didik pada } \\
\text { mitra yang bergerak } \\
\text { dalam bidang } \\
\text { pendidikan nonformal. }\end{array}$ & Ada \\
\hline 3 & $\begin{array}{l}\text { Peningkatan kwantitas } \\
\text { dan kualitas siswa }\end{array}$ & Ada \\
\hline 4 & $\begin{array}{l}\text { Peningkatan } \\
\text { pemahaman agama } \\
\text { dan ketrampilan } \\
\text { mempraktikan oleh } \\
\text { siswa }\end{array}$ & Ada \\
\hline 5 & $\begin{array}{l}\text { Jasa, model, rekayasa } \\
\text { sosial, sistem, belajar } \\
\text { mengajar pendidikan } \\
\text { nonformal }\end{array}$ & Ada \\
\hline 6 & Buku ajar & Draff \\
\hline
\end{tabular}

\section{METODE PELAKSANAAN}

\section{Metode pelaksanaan}

Kegiatan

Program

Kemitraan

Masyarakat Stimulus (PKMs) ini dilaksanakan melalui langkah-langkah sebagai berikut :

\subsection{Pemilihan sasaran}

Pemilihan sasaran Awalnya tim kegiatan PKMs ini melakukan observasi pada beberapa Lembaga pendidikan non formal Pasraman, yang terdapat di wilayah sekitar Lingkungan Panaraga Utara, Panaraga Selatan, Abiantubuh Utara, Lingkungan Abiantubuh Selatan dan
Abiantubuh Barat, Gedur, dan Kecamatan Cakranegara, Kecamatan Sandubaya, Kota Mataram, Propinsi Nusa Tenggara Barat. Setelah observasi dilakukan, dilanjutkan dengan memilih mitra yang berminat dan layak bekerja sama dengan tim PKMs ini.

\subsection{Mengidentifikasi masalah}

Langkah selanjutnya yang dilakukan tim PKMs ini adalah mengidentifikasi masalah yang ada pada mitra; 1) aspek peralatan/perlengkapan belajar, berkaitan dengan keterbatasan peralatan dan sarana belajar mengajar 2) aspek manajemen, klompok belajar pasraman belum memiliki legalitas ijin pasraman yang memadai dan tata laksana pembelajaran masih parsial 3) aspek sosialisasi, masih terbatas karena dilakukan dari mulut kemulut, plang nama penunjuk arah pasraman belum ada.

\subsection{Menyampaikan tawaran solusi kepada mitra}

Langkah berikutnya adalah memberikan tawaran solusi kepada mitra atas persoalan yang mereka hadapi. Langkah ini diharapkan dapat menjadi solusi tepat bagi mitra untuk menyelesaiakan masalah yang selama ini mereka alami. 
2. Tim Pelaksana

Tabel 5. Daftar nama tim pelaksana dan kepakaran.

\begin{tabular}{|l|l|l|l|l|}
\hline No & \multicolumn{1}{|c|}{ Nama } & Jabatan & Kepakaran & \multicolumn{1}{|c|}{ Uraian Tugas } \\
\hline 1 & $\begin{array}{l}\text { I Ketut Purwata } \\
\text { SH.,MH. }\end{array}$ & Ketua & $\begin{array}{l}\text { Pengembangan } \\
\text { SDM } \\
\text { atas semua } \\
\text { kegita-an PKMS, } \\
\text { pelapo- ran dan } \\
\text { publikasi }\end{array}$ \\
\hline 2 & $\begin{array}{l}\text { Dra. Siluh Putu } \\
\text { Damayanti,M.Pd. }\end{array}$ & Anggota & Pendidikan & $\begin{array}{l}\text { Bertanggung } \\
\text { jawab atas } \\
\text { pelaksanaan dan } \\
\text { pendidikan } \\
\text { management }\end{array}$ \\
\hline 3 & $\begin{array}{l}\text { Lalu Yulendra, } \\
\text { M.Par }\end{array}$ & Anggota & Pariwisata & $\begin{array}{l}\text { Penyuluhan } \\
\text { materi pariwisata } \\
\text { pendidikan }\end{array}$ \\
\hline 4 & $\begin{array}{l}\text { I Ketut bagiastra, } \\
\text { M.Pd }\end{array}$ & Anggota & Pendidikan & $\begin{array}{l}\text { Memberikan } \\
\text { materi pendidikan } \\
\text { management }\end{array}$ \\
\hline
\end{tabular}

3.Proses kegiatan atau tahapan/langkahlangkah kegiatan

\subsection{Permasalahan peralatan/perlengkapan}

1. Pasraman kurang dan tidak lengkap serta tidak mendukung situasi dan kondisi kekinian.

2. Sarana dan alat bantu belajar pasraman banyak yang tidak dapat dipergunakan karena rusak dan perawatan dan penyimpanan yang tidak memadai.

\subsection{Permasalahan Manajemen}

1. Mitra belum memiliki manajemen pengelolaan pendidikan Pasraman yang memadai.

2. Mitra belum memiliki lengkap memiliki perijinan/legalitas sebagai pendidikan pasraman dan ketersediaan tenaga pendidik

3. Mitra masih terbatas dalam penggunaan media sosialisasi untuk promosi dan belum ada plang papan nama mitra

4. Mitra belum memiliki catatan/laporan kegiatan dan keuangan secara baik dan tertib.

3.3.Metode pendekatan yang ditawarkan untuk menyelesaikan permasa - lahan mitra yang telah disepakati dalam pengabdian ini

1) Metode pelaksanaan yang ditawarkan dalam bidang peralatan/ perlengkapan telah disepakati a. Melakukan pendampingan untuk menata dan menghitung kebutuhan Peralatan/ perlengkapan untuk mendukung proses belajar mengajar sisie (siswa) pasraman, serta menyiapkan proposal untuk meyakinakan donatur untuk mendapat bantuan peralatan/perlengkapan yang di butuhkan.

b. Melakukan pendampingan untuk melakukan perbaikan, perawatan dan penyimpanan sarana dan alat bantu belajar pasraman agar tetap terawat dan selalu siap untuk digunakan mendukung proses belajar mengajar.

3.4. Metode pelaksanaan yang ditawarkan dalam bidang manajemen dan pemasaran dan telah disepakati

a. Melakuan pelatihan dan pendampingan untuk penata laksanaan manajemen pengelolaan pendidikan Pasraman yang memadai.

b. Melakukan pelatihan tentang perlunya perijia/legalitas kegiatan pendidikan pasraman dan melakukan pendampingan dalam pengurusannya, serta melakukan pendampingan dalam penyediaan tenaga pendidik.

c. Melakukan pelatihan dan pendampingan dalam memanfaatkan penggunaan media sosial on line baik PC maupun HP untuk promosi maupun proses belajar mengajar, serta melakukan pengadaan plang papan nama mitra.

d. Melakukan pelatihan dan pendampingan untuk pembuatan administarsi pendidikan pasraman serta melakukan catatan/laporan kegiatan dan keuangan secara baik dan tertib.

\section{Partisipasi Mitra dalam Pelaksanaan Program}

Partisipasi mitra terhadap program ini adalah mitra mencarikan informasi terkait peralatan/perlengkapan yang dibutuhkan dan harga per itemnya, serta merekap daftar nama donatur yang akan dihubungi untuk dapat mendonasi kebutuhan pasraman. Informasiinformasi tersebut penting untuk menentukan besaran pengajuan anggaran dan bagai mana melengkapinya. Disamping itu mitra dalam pelaksanaan program nantinya akan mengundang para sisie (siswa) dan para pengajar untuk dapat mengikuti pelatihan proses belajar mengajar pasraman yang efektif dengan menggunakan media sosial dan pelaksanaan administrasinya yang lebih 
inovatif, kreatif dan variatif dan juga mengundang dan masyarakat yang ada di wilayah sekitarnya tempat pasraman berada agar termotivasi untuk mau ikut serta untuk mendorong dan mengirim putra putrinya untuk ikut dalam kegiatan pendidikan pasraman, atau setidaknya dapat memahami bahwa pasraman memberikan nilai positif dalam memberikan pendidikan alternatif bagi putra putrinya, selain itu mitra berpartisipasi dalam mengikuti pendampingan pengelolaan manajemen pendidikan pasraman, administrasi, pelaporan, sosialisasi dan pendampingan dalam pembuatan ijin dan legalitas pendirian pasraman.

5. Evaluasi pelaksanaan program dan keberlanjutan program setelah selesai kegiatan PKMs dilaksanakan

Evaluasi dalam Program Kemitraan Masyarakat Stimulus (PKMs) ini, akan dilakukan kontrol/pengawasan secara bertahap terhadap pelaksanaan kegiatan tersebut dengan maksud, apabila terdapat adanya kesulitankesulitan yang dialami oleh mitra. Kesulitan tersebut seperti adanya kendala sarana dan prasarana, berupa peralatan belajar pemahaman untuk membuat laporan kegiatan, keuangan serta pemberdayaan sosialisasi pasraman, maka tim pengabdi akan segera membantu mitra mencarikan solusinya.

Keberlanjutan kegiatan PKMs ini, setelah selesai dilaksanakan akan direncanakan untuk melanjutkannya pada program yang sama namun di perluas jangkauannya yaitu Program Kemitraan Masyarakat (PKM). Atau Program Pengembangan Kewirausahaan (PPK), hanya beda skimnya Tujuan dari PPK adalah menciptakan wirausaha baru mandiri yang berbasis iptek dan meningkatkan keterampilan manajemen usaha bagi sisie (siswa) atau masyarakat di sekitar pasraman dengan menciptakan pelatihan kewirausahaan yang cocok bagi sisie pasraman dan masyarakat.

\section{KELAYAKAN PERGURUAN TINGGI}

Secara umum kualifikasi tim pelaksana pegabdian yang terlibat dalam kegiatan Program Kemitraan Masyarakat Stimulus internal ini (PKMs) ini memilki kompetensi keahlian yang mumpuni dalam melakukan kegiatan ini, karena ketua tim adalah pengajar mata kuliah Management Hotel, Management Sumber Daya Manusia dan Hukum Pariwisata di Sekolah Tinggi Pariwisata (STP) Mataram dan juga sekaligus juga aktif sebagai pengurus dan pembina kegiatan keumatan (organisasi sosial) yaitu sebagai pengurus Parisada Hindu Darma Indonesia (PHDI) Kota Mataram. Keahlian yang dimiliki sangat relevan dengan pelatihan yang dilakukan yaitu mitra Pasraman Swasta Pranawa yang diajarkan dalam kegiatan sosialisasi, dan workshop dalam menyebarkan hasil kegiatan belajar mengajar di Pasraman melalui media sosial seperti facebook, whatssup, istagram dan media sosial lainnya, dengan harapan banyak peserta didik dan masyarakat secar luas, sehingga tertarik dan mau ikut dalam kegiatan tersebut.

Anggota tim adalah staff pengajar di bidang pariwisata terutama mata kuliah yang terkait dengan pengembangan sumber daya manusia, proses supervisi dan ahli dalam bidang pengelolaan administrasi pendidikan formal dan non formal, serta merupakan praktisi organisasi sosial keumatan. Tim dalam hal ini memberikan gambaran kepada pengajar dan sisie untuk mengembangkan pendidikan non formal (Pasraman) di Lingkungan Abiantubuh menuju pusat pengembangan dan pendidikan non formal yang moderen, yang bidang keunggulannya adalah mencerdaskan dan mengembangkan srada bhakti yang mulia. Harapan tersebut sangat positip dalam memanfaatkan waktu bagi siswa dan masyarakat dalam kontek situasional masyarakat untuk melawan/mengkonter pengarus negatif kemajuan tehnologi informasi dan globalisasi khususnya di Lingkungan Abiantubuh.

\section{HASIL DAN LUARAN YANG DICAPAI 1. Partisipasi Mitra}

Program PKMs ini terlaksana dengan baik sesuai harapan karena:

1). Partisipasi aktif atau antusiasme Mitra menyiapkan:

a. Tempat atau lokasi dan waktu pelaksanaan, 
b. Konsumsi selama berlangsungnya kegiatan, prasarana dan sarana pen-dukung kegiatan lainnya,

2). Keikutsertaan aktif atau antusias Mitra mengikuti seluruh rangkaian kegiatan sesuai dengan jadwal dan perencanaan kegiatan (rundown) acara pelatihan secara serius,

3). Disamping itu kesedian dan keikut sertaan kepala kepala lingkungan dan Manggala Pura Dalem Swasta Pranawa ikut aktif mendorong, memotivasi, terlibat serta mengfasilitasi terselenggaranya kegiatan PKMs. Disamping itu penyediaan tempat proses belajar mengajar bagi sisie dan tempat proses administrasi dan sekretariat Pasraman.

\section{Evaluasi Pelaksanaan PKMS}

Tahapan evaluasi dalam PKMs ini antara lain sebagai berikut:

1).Merumuskan strategi evaluasi (perencanaan, persiapan, pelaksanaan, dan evaluasi).

2).Menentukan tingkat capaian atau keberhasilan program (ouput dan outcomes). Output terkait penyajian, penguasaan dan penyerapan materi, kemampuan mempraktekkan. Sedangkan dimensi outcomes peserta memiliki keprakarsaan berinteraksi dengan wisatawan.

3).Menyusun hasil monitoring dan evaluasi sebagai dasar penyusunan laporan dan rekomendasi akhir PKMs.

\section{Manajemen/Tata Kelola Organisasi}

Manajemen/ tata kelola organisasi dan administrasi yang masih rendah di atasi dengan diskusi dengan ketua Pasraman, donatur dan pengurus Pura Swasta Pranawa. Hasil diskusi adalah walaupun kelompok bela.

Pasraman sudah ada ketua, sekertaris dan bendahara namun dalam penerapannya tidak semua tugas jabatan tersebut dilaksanakan sesuai dengan fungsi dan tugas masing-masing dalam pelaksanaan proses belajar mengajar. Dalam pengabdian ini diberikan pengarahan atau sosialisasi fungsi dan tugas dari masingmasing jabatan yang dipegang dan administrasi yang diperlukan, dan diharapkan konsisten dalam aplikasinya.

Disamping itu di berikan pelatihan tehnik dan tatacara pengurusan ijin dan legalitas kelompok belajar pendidikan non formal pasraman untuk pengembangan dan peningkatan peserta didik kedepannya. Disamping itu untuk memperluas sosialisasi agar dapat menjangkau masyarakat pengempon ( pengampu pura) wilayah Pasraman maupun diluar wilayah pengempon. Kemudian memberikan pelatihan kepada kelompok belajar non formal Pasraman Swasta Pranawa untuk memanfaatkan tehnologi seperti gawai (gatget) whatssup, twiiter, facebook, istagram internet berbasis on line, dan pembuatan plang papan nama Pasraman. Membantu membuat dan membimbing pelatihan mebuat administasi dan catatan pengelolaan keuangan sederhana dan membuat laporan kegiatan belajar mengajar.

Dalam pengabdian ini juga dijabarkan tugas dari masing-masing jabatan kegiatan kelompok belajar Pasraman mulai dari ketua kelompok sampai dengan bendahara. Berikut adalah proses wawancara antara ketua PKMs dengan ketua Kelompok belajar Pasraman Swasta Pranawa Abiantubuh Selatan pada hari Minggu tanggal 12 Januari 2020 pukul 10.00 WITA.

\section{Gambar 4. Wawancara Ketua PKMs dengan ketua kelompok belajar Pasraman Swasta Pranawa Abiantubuh.}

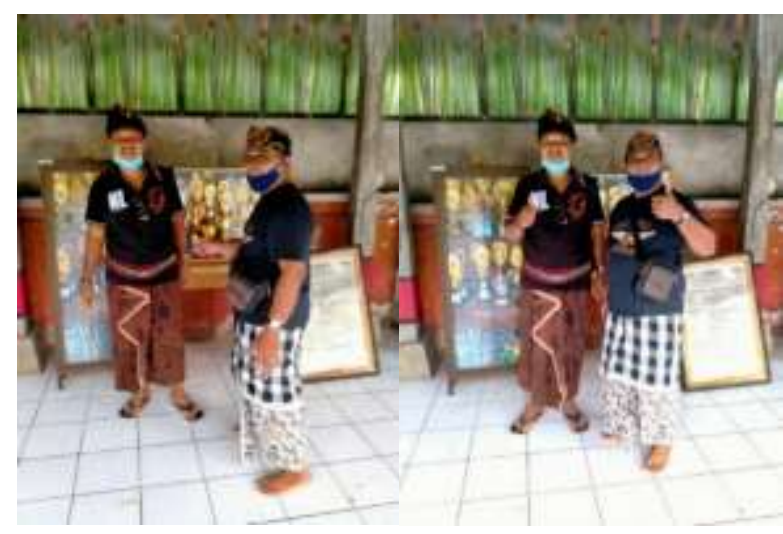

Hasil dari wawancara ini adalah observasi awal terkait dengan bantuanyang dibutuhkan oleh kelompok belajar Pasraman Swasta Pranawa Abiantubuh. 
Gambar 5. Survey awal ke lokasi Pasraman Swasta Pranawa

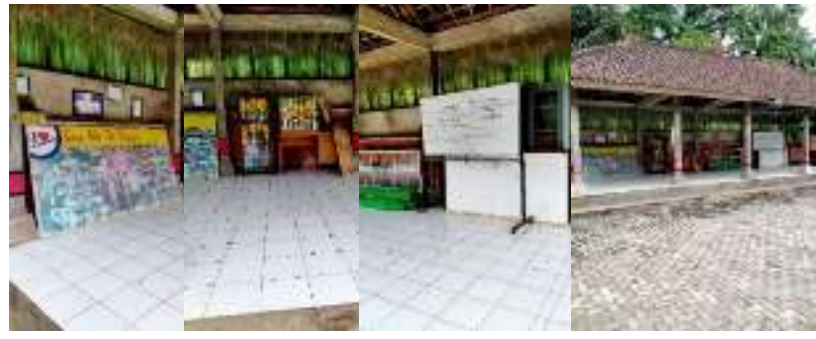

Para pengurus dan pengelola Pasraman masih kurang paham dan masih berpikir bahwa pengelolaan pasraman secara tradisional (terbatas pada media lama dan sistem lama). Pasraman sebagai salah satu pendidikan non formal masih dipandang sebagai pendidikan biasa saja dibanding pendidikan formal sehingga jarang dimanfaatkan sebagai tempat yang efektif untuk pembentukan dan pembangunan karakter yang efektif. Disamping itu pengetahuan organisasi dan management pendidikan non formal pasraman yang masih minim (Tata Kelola). Kurangnya militansi masyarakat dalam mendorong sisie baru agar mau masuk ke Pasraman sebagai siswa dan kurangnya masyarakat dalam memperdayakan tamatan sisie memperkecil dan mengancam keberlangsungan lembaga Pasraman kedepannya. Kurangnya keterampilan dan kreasi dalam memanfaatkan tehnologi dan sosial media menyebabkan kurang luasnya jangkauan untuk menarik sisie baru dan penggunaan media pembelajaran yang kreatif dan efektif. Tindak lanjut dari hasil wawancara yang telah dilakukan ini adalah dengan diadakan nya sosialisasi. Berikut adalah foto kegiatan sosialisasi terhadap kelompok belajar non formal Pasraman Swasta Pranawa, Lingkungan Abiantubuh, Kecamatan Cakranegara, Kota Mataram, Propinsi NTB.
Gambar 6. Kegiatan Sosialisai Kelompok belajar non formal Pasraman Swasta Pranawa

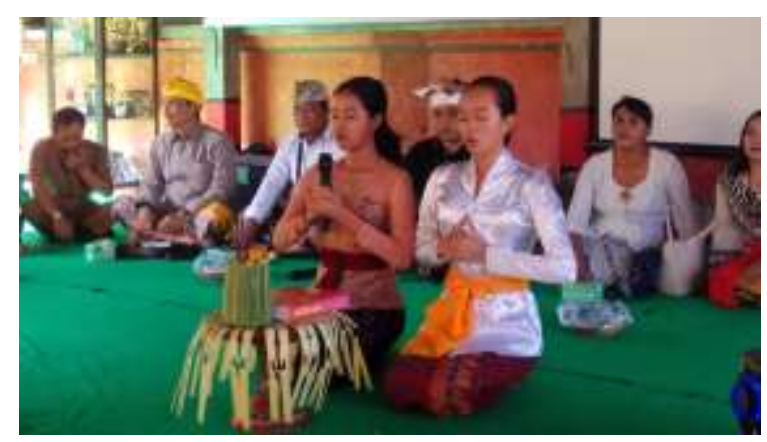

Gambar 7. Spanduk Sosialisasi

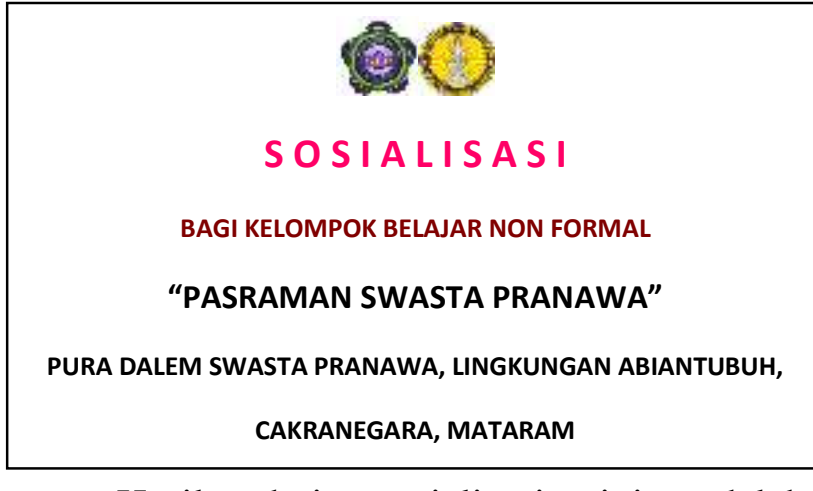

Hasil dari sosialisasi ini adalah memberikan pemahaman kepada pengelola (Manggala Pura, Ketua dan jajarannya), para brahmacari (pembina dan pendididik), bagaimana pentingnya peralatan/perlengkapan pendukung keberlanjutan proses belajar mengajar. Kemampuan untuk membuat proposal dan mengajukan ke para donatur untuk mendapatkan bantuan penunjang Pasraman, kegiatan tersebut berhasil mendapatkan bantuan berupa peralatan/perlengkapan penunjang selajar seperti laptop, printer, LCD proyektor, lemari buku, meja belajar duduk, karpet duduk, white board magnet, wareles, sekat pembatas ruang, cok roll dan lain-lain. 


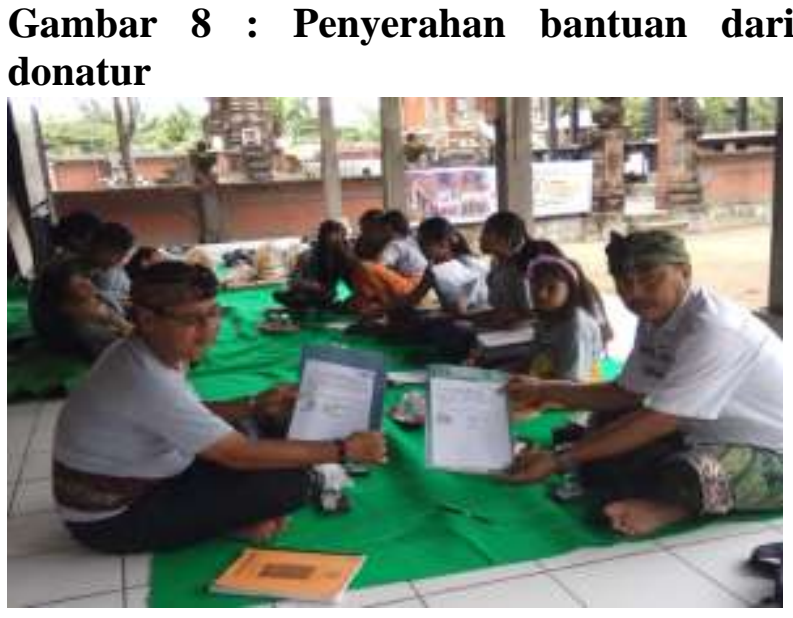

Sosialisasi ini dihadiri oleh 15 Orang baik Ibu-Ibu maupun Bapak-Bapak pengelola dan Brahmecari. Hasil sosialisasi juga untuk memberikan pelatihan dan pendampingan bagaimana cara melakukan perbaikan, perawatan dan penyimpanan sarana dan alat bantu belajar pasraman agar tetap terawat dan selalu siap untuk digunakan mendukung proses belajar mengajar.

Hasil sosialisasi juga memberikan pelatihan termasuk pendampingan mengenai bagai mana mengatur dan melakukan pengelolaan adminstrasi proses belajar mengajar di Pasraman, seperti mengelola jadwal, absensi, administrasi belajar mengajar, administrasi keuangan, adminstrasi pembelajaran diluar lokasi, secara manual maupun dengan perlatan komputer baik dengan off line maupun dengan on line.

Sosialisasi juga memberikan pelatihan tentang metode belajar mengajar dengan mengunakan metode pendidikan diluar sekolah non formal bagi para brahmecari maupun calon brahmecari. Melakukan pendampingan untuk mendapatkan tenaga pendidik dengan melakukan kerja sama dengan lembaga pendidikan seperti Sekolah Tinggi Angama Hindu Negeri (STAHN) Gde Puja Mataram.

Sosialisasi juga memberikan pelatihan dan pendampingan dalam memanfaatkan penggunaan media sosial on line baik dengan personal komputer (PC) maupun hand phone (HP) untuk bagaimana memanfaatkan media tersebut untuk melakukan pengenalan/promosi tentang aktifitas dan kegiatan pasraman kepada masyarakat sehingga dapat menjangkau dan menjaring sisie lebih banyak dan konsisten, disamping itu pula tim PKMs membantu untuk mengadakan papan plang Pasraman. Dalam sosialisasi juga memberikan pelatihan dan pendampingan memanfaatkan media ini untuk melakukan proses belajar mengajar dengan mengunakan media virtual dimana semasa kegiatan PKMs berjalan, daerah kita dilanda pandemi COVID-19 .

Hasil sosialisasi juga memberikan pelatihan tentang perlunya memiliki perijinan/legalitas yang formal guna menunjang kegiatan proses belajar mengajar di pasraman, agar tercatat supaya memiliki pengakuan dan memiliki legalitas dalam melakukan komunikasi dan mengadakan dan menggali bantuan baik kepada pemerintah maupun lembaga-lembaga di luar pemerintah, serta melakukan pendampingan.

Tim PKMs internal dari STP Mataram mengalami kendala pada saat pelaksanaan pengabdian terkait dengan pengaturan waktu pelaksanaan kegiatan pengabdian dikarenakan sebagian anggota kelompok belajar Pasraman adalah juga pelajar di sekolah formal, dan disamping itu bagi Brahmacari (pengajar) serta pengelola merupakan tenaga

kerja atau pekerja pada pemerintahan dan swasta, sehingga pelaksanaan kegiatan pengabdian selalu mengambil waktu hari minggu dan atau pada saat libur sekolah atau pada saat liburan nasional. Sehingga pada saat akan melaksnakan kegiatan sosialisasi harus menjadwalkan pada jam yang tepat dan waktu yang tidak terlalu lama. Disamping itu dengan adanya situasi pandemi Covid-19, menyebabkan beberapa kegiatan untuk berkumpul mejadi sulit dilaksanakan bahkan tidak bisa dilakukan karena adanya pembatasan, oleh karena itu beberapa kegiatan di efisiensikan dan pengambilan gambar kegiatan menjadi tidak bisa dilaksanakan.

Beberapa anggota kelompok belajar Pasraman dan masyarakat menganggap bahwa kegiatan tersebut tidak begitu menarik dan tidak penting bagi mereka. Mereka beranggapan bahwa ke giatan lain lebih penting ketimbang mengikuti acara sosialisasi yang dilakukan oleh tim PKMs internal dari STP Mataram, padahal 
sebelumnya tim telah bersepakat dengan ketua dan sekertaris kelompok belajar pasraman.

Dalam kegiatan sosialisasi beberapa pengelola pasraman dan sisie menanyakan terkait dengan cara pengelolaan dan apa bentuk kelulusan sebagai sisie pasraman. Terkait dengan hal tersebut tim dari STP Mataram menjawab pertanyaan demi pertanyaan dan tindak lanjut dari kegiatan sosialisasi ini adalah diadakannya pendampingan dan jika memungkinkan akan dilanjutkan dengan PKM lain yang lebih luas.

\section{Rendahnya SDM Mitra Pada Aspek Keterampilan (Skill) Dan Pengetahuan (Knowledge) Tentang tata kelola management pendidikan Pasraman.}

Rendahnya SDM pada aspek keterampilan (skill) dan pengetahuan (knowledge) tentang proses tata kelola management administrasi proses belajar mengajar pendidikan non formal pasraman serta penguasaan media sosial on line dan virtual secara kreatip oleh pengelola, Brahmecari dan sisie kelompok belajar Pasraman, metode yang digunakan oleh tim PKMs adalah dengan mengadakan sosialisasi. Hasil dari sosialisasi ini 15 orang Brahmecari (pengajar) dan pengelola tata kelola administrasi Pasraman dan penggunaan media sosial yang ada. Dari hasil sosialisasi peserta (sisie) lebih paham dan mengerti tentang proses belajar mengajar di Pasraman dan menggunakan media sosial untuk proses pembelajaran yang lebih efektif dan lebih banyak memiliki pariasi yang menarik dalam pembelajaran di Pasraman.
Gambar 9. Kegiatan Kelompok belajar Pasraman Swasta Pranawa

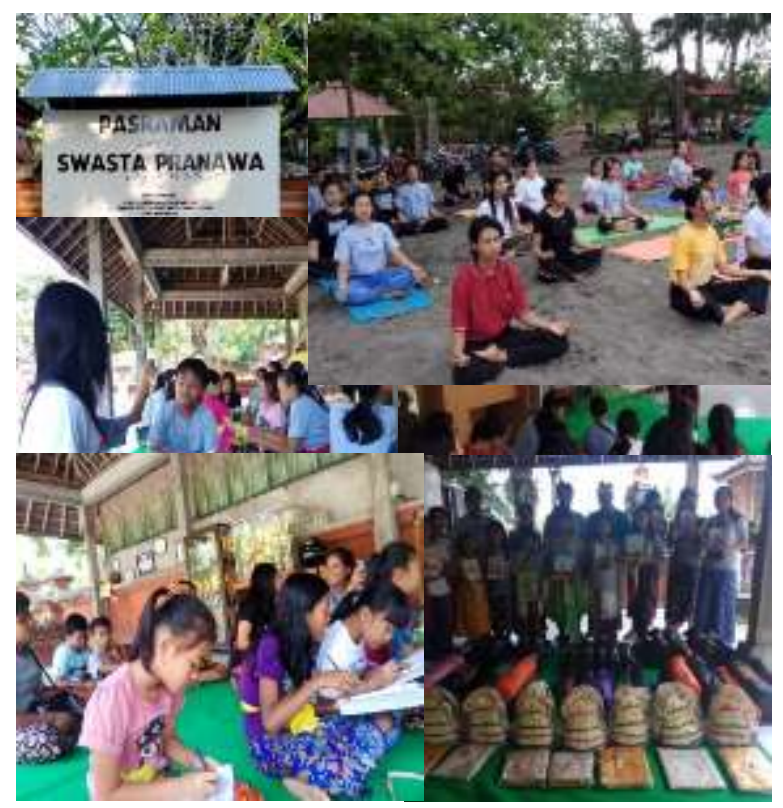

\section{PENUTUP}

\section{Kesimpulan.}

Kesimpulan dari hasil pengabdian kepada masyarakat ini adalah :

a. Masih rendah pemahaman dan pengetahuan pengempon (masyarakat) Pura Dalem Swasta Pranawa (PDSP) sebagai wadah induk organisasi Pasraman, mengenai keberadaan, peran dan manfaat kegiatan kelompok belajar Pasraman saat ini dan kedepannya. Setelah ada PKMs masyarakat memahami dan mengetahui manfaat dan arti pentingnya kelompok belajar Pasraman bagi sisie dan masyarakat. Sedang untuk pembina menjadi landasan untuk menentukan kebijakan dan arah pasraman. Bagi pengelola dan Brahmecari (pengajar)paham tentang pemanfaatan administrasi pendidikan, dan memanfaatkan sumberdaya yang ada Pasraman untuk memperlancar proses belajar mengajar dan meningkatkan peran dan keberlanjutan Pasraman.

b. Kelompok belajar Pasraman Swasta Pranawa telah memperoleh kemampuan dalam pengelolaan administrasi pendidikan Pasraman, pengadaan sarana 
pendidikan, perawatan dan perbaikan peralatan, pemanfaatan peralatan secara maksimal untuk melakukan proses pembelajaran dan melakukan promosi dengan teknologi informatika komputer dan gawai (on line atau off line) serta pemberdayaan Pasraman yang bermanfaat untuk masyarakat.

\section{Saran}

Saran dari kegiatan pengabdian ini adalah Mitra membutuhkan pendampingan yang berkelanjutan dalam pelaksanaan proses belajar mengajar, pengembangan dan keberlanjutan Pasraman, sehingga bisa di jadikan sebagai alternatif yang positif dalam penanganan pendidikan non formal dewasa ini.

\section{DAFTAR PUSTAKA}

[1] Pendidikan Non Formal: Pengertian, Tujuan, Jenis, dan Contohnya, URL : https:// Www. maxmanroe.com/vid/umum/pendidikannon-formal.html, di posted bulan Desember 2019.

[2] Lima rekomendasi pendidikan non formal yang berkualitas \& bervariasi non formal, URL: https://www.brilio.net/creator/5rekomendasi-pendidikan-non-formal-yangberkualitas bervariasi- 3c74d1.html,

[3] Pasraman dan pembentukan karakter bangsa,URL:

https://phdi.or.id/artikel/pasraman-danpembentukan-karakter-bangsa, di posted 2019.

[4] Sekolah Hindu Terhadang Krisis Guru, URL:

https://www.nusabali.com/berita/53224/sekol ah-hindu terhadang-krisis-guru. 